\title{
Pengembangan Media Pembelajaran Berbasis Multimedia Menggunakan Macromedia Flash Dalam Fiqih Islam Materi Pokok Sholat Dan Zakat
}

\author{
Said Nur Alim \\ ${ }^{1}$ Pascasarjana Institut Pesantren KH. Abdul Chalim Pacet Mojokerto, Indonesia \\ e-mail: ayuusundarii@gmail.com
}

Submitted: 05-01-2021 Revised : 15-03-2021 Accepted: 14-04-2021

\begin{abstract}
Abstrak, The development of science and technology increasingly encourages reform efforts in the use of technological results in the learning process. Teachers are required to be able to use these tools in accordance with the developments and demands of the times. And it is a must for teachers to be able to master technology in order to achieve the expected learning objectives, the problems in this study are: (1) how to develop multimedia-based learning media using Macromedia Flash in Fiqh learning the subject matter of Prayer and Zakat? (2) how is the effectiveness of multimedia-based learning media using Macromedia Flash in Figh learning the subject matter of Prayer and Zakat? The development was carried out using the Research and Development (R\&D) method with several stages, namely: analyzing potential and papers, gathering information, product design, design validation, design revision, product testing, product revision, product usage trials. The results of the design validation stages, product trials and usage trials are used to improve the developed products for maximum results. Based on the trials that have been carried out, the results are as follows: a) pre-test and post-test with an initial average of 54.57 and an increase after learning with a final score of 86.85 , thus the post-test average of 32.28 can be categorized in good criteria. b) Based on the practical analysis conducted in the field, some teachers and students gave a positive response to the developed product. The effectiveness of learning using Macromedia Flash, The increase in the average value of pre-test and post-test that has been carried out by respondents from one lesson, there is an increase of 32,285714286 from 54,571428571 to 86.857142857, There is a positive response of students to the development of media using Macromedia flash i.e. $79 \%$ of students categorize very well, $13 \%$ of students categorize good and $8 \%$ of students categorize enough.
\end{abstract}

Keywords: Macromedia Flash 8, Prayer and Zakat Materials, Development of Teaching Materials

doi) https://dx.doi.org

How to Cite Nur Alim, S. (2021). Pengembangan Media Pembelajaran Berbasis Multimedia Menggunakan Macromedia Flash Dalam Fiqih Islam Materi Pokok Sholat Dan Zakat. Munaddhomah: Jurnal Manajemen Pendidikan Islam, 2(2), 2021

\section{PENDAHULUAN}

Manusia membutuhkan pendidikan dalam kehidupannnya. Pendidikan merupakan usaha agar manusia dapat mengembangkan potensi dirinya melalui proses pembelajaran dan atau cara lain yang dikenal dan diakui oleh masyarakat. Undang-Undang Dasar Negara Republik Indonesia Tahun 1945 Pasal 31 ayat (1) menyebutkan bahwa setiap warga negara berhak mendapat pendidikan, dan ayat (3) menegaskan bahwa Pemerintah mengusahakan dan menyelenggarakan satu sistem pendidikan nasional yang meningkatkan keimanan dan ketakwaan serta akhlaq mulia dalam rangka mencerdaskan kehidupan bangsa yang diatur dengan undang-undang. Untuk itu, seluruh komponen bangsa wajib mencerdaskan kehidupan bangsa yang merupakan salah satu tujuan Negara Indonesia (Ismanto et al., 2014). 
Berbagai pemahaman tentang multimedia terus berkembang seiring dengan perkembangan Teknologi Informasi dan komunikasi baik aspek software maupun hardware yang mendukungnya. Menurut sudut pandang ahli media, sebelum berkembangnya dunia Teknologi Informasi, bahwa multimedia dipandang sebagai suatu pemanfaatan "banyak" media yang digunakan dalam suatu proses interaksi penyampaian pesan dari sumber pesan kepad Manusia membutuhkan pendidikan dalam kehidupannnya. Pendidikan merupakan usaha agar manusia dapat mengembangkan potensi dirinya melalui proses pembelajaran dan atau cara lain yang dikenal dan diakui oleh masyarakat. Undang-Undang Dasar Negara Republik Indonesia Tahun 1945 Pasal 31 ayat (1) menyebutkan bahwa setiap warga negara berhak mendapat pendidikan, dan ayat (3) menegaskan bahwa Pemerintah mengusahakan dan menyelenggarakan satu sistem pendidikan nasional yang meningkatkan keimanan dan ketakwaan serta akhlaq mulia dalam rangka mencerdaskan kehidupan bangsa yang diatur dengan undang-undang. Untuk itu, seluruh komponen bangsa wajib mencerdaskan kehidupan bangsa yang merupakan salah satu tujuan Negara Indonesia.

Berbagai pemahaman tentang multimedia terus berkembang seiring dengan perkembangan Teknologi Informasi dan komunikasi baik aspek software maupun hardware yang mendukungnya. Menurut sudut pandang ahli media, sebelum berkembangnya dunia Teknologi Informasi, bahwa multimedia dipandang sebagai suatu pemanfaatan "banyak" media yang digunakan dalam suatu proses interaksi penyampaian pesan dari sumber pesan kepada penerima pesan, salah satunya dalam konteks pembelajaran antara guru dan peserta didik(Taufiq Ari Nugroho \& ., 2019).

Namun demikian, sebagai akademisi atau praktisi dalam memandang dan memahami multimedia, hendaknya kita lebih bijak dan tetap berlandaskan pada temuan dan paradigma terdahulu yang mengawalinya. Sebagai pihak yang bertanggung jawab atas perkembangan keilmuannya teruslah melakukan inovasi dan perekayasaan secara lebih bijak, kreatif, dan unggul melalui pemanfaatan berbagai sudut pandangan dan sumber daya yang ada dengan landasan teori dari para pakar sebelumnya (Deni Darmawan dan kunkun Nur Fauzi, 2016). Teori belajar kognitif berpendapat bahwa tingkah laku seseorang ditentukan oleh presepsi serta pemahamannya tentang situasi yang berhubungan dengan tujuan belajarnya. Belajar merupakan perubahan presepsi dan pemahaman yang tidak selalu dapat dilihat sebagai tingkah laku yang tampak. Teori ini memandang belajar merupakan proses internal yang mencakup ingatan, retensi, pengolahan informasi, emosi dan faktor-faktor lain, belajar merupakan aktivitas yang melibatkan proses berfikir yang kompleks(Hakim, 2018).

Simonson dan Thomson memberikan gambaran tentang penggunaan teori kognitif sebagai landasan dalam pengmbangan media pembelajaran. Mereka berpendapat bahwa teori kognitif mengutamakan konseptualisasi proses pembelajaran peserta didik(Wiyani, 2013). Teori ini memfokuskan pada eksplasi cara informasi itu diterima, diingat, dikelola, dan digunakan oleh otak. Pembelajaran seharusnya disusun dan disampaikan dalam suatu cara yang selalu memberikan pujian pada struktur kognitif dan tingkat pengalaman peserta didik(Ismanto et al., 2014). Media pembelajaran bisa dipahami sebagai media yang digunakan dalam proses dan tujuan pembelajaran. Pada hakikatnya proses pembelajaran juga merupakan proses komunikasi, maka media pembelajaran bisa dipahami sebagai media komunikasi yang dgunakan dalam konteks dan untuk mencapai tujuan pembelajaran. Dalam proses komunikasi tersebut, media pembelajaran memiliki peran penting sebagai sarana untuk menyalurkan pesan pembelajaran(Kusumaningrum et al., n.d.)

Namun pada kenyataannya, Banyak siswa yang merasa jenuh dan malas untuk belajar pelajaran Pendidikan Agama Islam, karena kurangnya inovasi dalam pembelajaran. Penggunaan metode pembelajaran guru masih cenderung konvensional dan bersifat monoton, hampir tanpa variasi kreatitifitas(Zuhriyah, 2020). Sebagian besar guru belum dapat memanfaatkan penggunaan media pembelajaran yang berbasis computer. Penggunaan Macromedia Flash dapat membuat media pembelajaran (prensentasi) yang menarik, sehingga dapat membantu siswa SMP/MTs dalam memahami materi Sholat dan Zakat. 
Sehingga penulis tertarik untuk meneliti tentang bagaimana mengembangkan media pembelajaran berbasis multimedia menggunakan Macromedia Flash dalam pembelajaran Fiqih materi pokok Sholat dan Zakat di SMPU BP Amanatul Umah Pacet? Dan bagaimana efektifitas media pembelajaran berbasis multimedia menggunakan Macromedia Flash dalam pembelajaran Fiqih materi pokok Sholat dan Zakat di SMPU BP Amanatul Umah Pacet?

\section{METODE PENELITIAN}

Pendekatan yang digunakan dalam penelitian ini adalah metode penelitian dan pengembangan atau Research \& Development (R\&D). Metode penelitian dan pengembangan adalah metode penelitian yang digunakan untuk menghasilkan produk tertentu dan menguji keefektifan produk tersebut(Sugiono, 2015).

\section{Model Pengembangan}

Model yang digunakan dalam penelitian dan pengembangan ini adalah model The DDD-E ( Decide, Design, Develop, Evaluate ). (Amalia, 2020)

Pada model ini pengembangan multimedia melalui empat tahapan yaitu : a. mengambil keputusan, b. membuat desain, c. mengembangkan produk, dan d. evaluasi. Tahapan pengembangan multiedia model DDD-E dapat dijelaskan sebagai berikut:

\section{Mengambil keputusan (Decide)}

Tahap ini digunakan oleh berbagai variabel, misalnya ketersediaan hardware, software, waktu dan biaya. Setelah berbagai variabel dapat terpenuhi selanjutnya dibutuhkan pemikiran apakahmultimedia yang dikembangkan akan efektif untuk memperbaiki hasil belajar dan pertimbangan - pertimbangan lain, diantaranya :('Peran Sistem Informasi Manajemen (SIM) Dalam Pengambilan Keputusan', 2013)

1) multimedia yang dikembangkan harus sesuai dengan siswa

2) multimedia harus sesuai dengan kurikulum

3) kemampuan siswa menggunakan komputer dan alat multimedia.

\section{Membuat disain (Design)}

Pada tahap ini dikembangkan disain multimedia yang dibuat, meliputi hal - hal sebagai berikut :

\section{Analisis materi (content)}

Elemen penting dalam multimedia untuk pendidikan adalah bahan ajar (materi subjek) yang digunakan dalam bentuk digital. Pengelolaan bahan ajar atau pengolahan materi subjek harus sesuai dengan struktur keilmuan dan teori pembelajaran.

\section{Flowchart}

Flowchart disebut juga diagram tampilan yaitu diagram yang memberikan gambaran alir dari satu scane ( tampilan ) ke scane lainnya. Dalam flowchart view dapat dilihat komponen yang terdapat dalam suatu scane dengan penjelasan yang diperlukan.

Storyboard

Storyboard merupakan deskripsi dari setiap scane yang secara jelas menggambarkan objek multimedia serta perilakunya yang meliputi tampilan visual, audio, durasi, beserta keterangan - keterangan lain yang diperlukan sehingga gambaran multimedia yang akan dikembangkan dapat terlihat dengan jelas.

Mengembangkan produk (develop)

pada tahap ini dikembangkan elemen - elemen multimedia yang dibutuhkan dalam multimedia, seperti teks, grafiks, animasi, audio dan video. Setelah elemen - elemen media dibuat, selanjutnya dipilih software untuk pembuatan multimedia. Ada beberapa software pembuatan multimedia diantaranya :

1) Program presentasi, misalnya: power point 
2) Program Hypermedia, misalnya: makromedia director

3) Program web, misalnya: makromedia dreamweaver

4) Program video, misalnya: windows movie maker.

Evaluasi (evaluate)

Tahap terakhir dari pengembangan multimedia adalah evaluasi. Evaluasi pengembangan multimedia meliputi evaluasi terhadap content, flowchart view, storyboard dan produk multimedia yang dikembangkan(Sya'bani et al., 2020)

Prosedur Penelitian dan Pengembangan

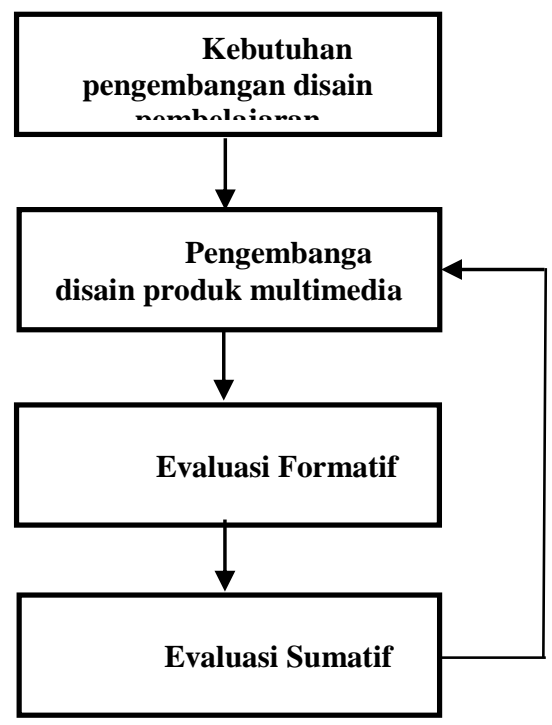

Gambar 3.1 Bagan Prosedur penelitian dan pengembangan

\section{Uji Coba Produk}

Untuk dapat menghasilkan produk tertentu digunakan penelitian yang bersifat analisis kebutuhan dan untuk mengkaji keefektifan produk tersebut supaya dapat diterima di masyarakat luas, maka diperlukan penelitian untuk menguji keefektifan produk dengan melakukan uji coba.

\section{Desain Uji Coba}

Uji coba pada produk media pembelajaran ini dilakukan dengan dua tahap, yaitu : 1) Tahap pertama dilakukan dengan meminta seorang ahli media pembelajaran dari Dosen Jurusan Pendidikan Agama Islam Institut KH. Abdul Chalim untuk mengevaluasi produk menggunakan Macromedia Flash dari sisi media pembelajaran. 2) Tahap kedua dilakukan dengan meminta seorang ahli materi pembelajaran dari Dosen Jurusan Pendidikan Agama Islam Institut KH. Abdul Chalim untuk mengevaluasi produk menggunakan Macromedia Flash dari sisi media pembelajaran.

Evaluasi dilakukan untuk memvalidasi produk, dimana dalam penelitian dan pengembangan ini validasi adalah kegiatan yang dilakukan untuk memperoleh pembelajaran dengan media yang layak dilihat dari segi materi dan media. Setelah uji coba dilakukan maka tahap berikutnya adalah melakukan perbaikan produk dengan mempertimbangkan saran dan masukan dari ahli media dan materi.

\section{Subjek Uji Coba}

Subjek uji coba produk ini adalah kelas VIII SMP/MTs dengan standar kompetensi dan kompetensi dasar yang ditetapkan sebagai mana tercantum dalam silabus mata pelajaran PAI untuk kelas VIII SMP/MTs. 


\section{Jenis Data}

Data yang dikumpulkan pada pengembangan media ini berupa data kuantitatif sebagai data pokok dan data dari ahli pembelajaran. Data tersebut memberi gambaran mengenai kelayakan produk yang dikembangkan.

Data dari ahli materi: Data dalam penelitian ini diperoleh dengan cara memberikan lembar evaluasi yang berisi penilaian terhadap pembelajaran dan isi media.(Barkah \& Zakiah, 2017)

Data dari ahli media: Data dalam penelitian ini diperoleh dengan cara memberikan lembar evaluasi yang berisi penilaian terhadap tampilan dan pemrograman media. ${ }^{1}$

\section{Instrumen Pengumpul Data}

Instrumen penelitian merupakan alat yang akan digunakan untuk memperoleh data menjawab dan memecahkan masalah yang berhubungan dengan pertanyaan penelitian. Dalam penelitian pengembangan ini instrumen pengumpulan data yang digunakan adalah kuesioner (angket).

Data kuantitatif yang diperoleh melalui kuesioner penilaian dianalisis dengan teknik analisis deskriptif kuantitatif yang diungkapkan dalam distribusi skor dan persentase terhadap kategori skala penilaian yang telah ditentukan. Setiap pertanyaan di beri bobot 1, 2, 3, 4 dan 5, yang diuraikan sebagai berikut:

Sangat layak : 5

Layak : :4

Cukup layak : 3

Kurang layak : 2

Tidak layak $: 1$

\section{PENELITIAN DAN PEMBAHASAN}

\section{Pembahasan}

\section{Media Pembelajaran}

Media menurut Heinich, dkk adalah "a channel of communication". Dijelaskan lanjut oleh Heinich, dkk jika dalam bahasa latin media adalah "between" yang sama halnya dengan "anything that carries information between a source and receiver", yaitu bahwa media merupakan pembawa informasi dari sumber ke penerima. Pembawa informasi ini dapat berupa manusia dan benda yang mampu memperjelas informasi sehingga tidak terjadi kesalahan informasi dan diharapkan informasi yang diterima (receiver) penerima sesuai dengan sumber (source). Sedangkan Hamalik menyatakan media pendidikan adalah alat, metode, dan teknik yang digunakan dalam rangka lebih mengefektifkan komunikasi dan interaksi antara guru dan siswa dalam proses pendidikan dan pengajaran di sekolah.

Jadi, media pembelajaran adalah segala sesuatu yang digunakan untuk menjelaskan konsep pembelajaran dari materi yang bersifat abstrak menjadi nyata sehingga dapat merangsang pikiran, perasaan, perhatian dan minat siswa yang menjurus kearah terjadinya proses belajar mengajar. Penggunaan media dalam pembelajaran sangat dianjurkan, karena dengan memanfaatkan media yang sesuai dengan materi pembelajaran akan lebih efektif dengan langsung memperagakan dan melakukan percobaan. Selain itu dengan menggunakan media, pembelajaran PAI yang dikenal siswa sebagai mata pelajaran yang religius dan sukar di pelajari, akan menjadi lebih mudah di pahami, menyenangkan bagi siswa dan guru dapat lebih kreatif dalam menyampaikan materi pembelajaran.

Proses belajar mengajar, ada dua unsur yang amat penting yaitu metode mengajar, dan media pengajaran dan keduanya sangat berkaitan. Pemilihan metode mengajar akan mempengaruhi jenis media pengajaran yang akan dipergunakan. Perlu diingat bahwa dalam 
suatu proses belajar mengajar dimungkinkan menggunakan metode mengajar lebih dari satu sesuai strategi mengajar yang dipilih oleh guru (Universitas Muhammadiyah Surakarta . Sekolah Pascasarjana, 2016).

Hamalik, menyatakan bahwa pemakaian media pengajaran dalam proses belajar dapat membangkitkan keinginan dan minat yang baru, membagikan motivasi dan rangsangan kegiatan belajar, dan bahwa akan membawa pengaruh-pengaruh psikologis terhadap siswa. Selain membangkitkan motivasui dan minta siswa, media pengajaran juga membantu siswa meningkatkan pemahaman untuk mencapai kemampuan menguasai metodologi media pengajaran tersebut.

Yudi Munadi menyatakan bahwa media pada dasarnya adalah "bahasanya guru". Artinya dalam proses penyampaian pesan pembelajaran, guru harus pandai memilih "bahasa apa" yang paling mudah dimengerti dan dipahami siswanya. Apakah pesan disampaikan melalui bahasa verbal, bahasa visual, atau bahasa non verbal lainya; apakah pesan itu disalurkan melalui peralatan atau melalui pengalaman langsung (Simangunsong \& ., 2015).

\section{Multimedia}

Pengertian Multimedia

Multimedia menurut Rob Philips : "The Multimedia component is characterized by the presence of the teks, pictures, sound, animation, and video; some or all of which are organized intosome coherent program". Komponen multimedia ditandai dengan adanya teks, gambar, suara, animasi, suara, dan video; beberapa atau semuanya diatur dalam progam yang berkesinambungan.

Sementara Heinich mendefinisikan multimedia sebagai kombinasi dua atau lebih format media yang dipadukan secara integrative sehingga menghasilkan program informasi atau program pendidikan.

Multimedia dapat berfungsi menjadi sebuah sistem komunikasi. Menjadi sebuah sistem karena merupakan sekumpulan obyek yang berhubungan dengan bekerja sama untuk menghasilkan suatu hasil yang diinginkan. Di dalam penggunaan multimedia memerlukan hardware (perangkat keras) yang berfungsi untuk memfasilitasi penyampaian materi software (perangkat lunak) yang berisi program-program yang akan di sampaikan. Selain itu dapat pula melibatkan alat-alat lain yang menunjangsistem multimedia tersebut agar mendapatkan penyajian audio visual yang penuh. Multimedia memungkinkan pemakai computer untuk mendapat output dalam bentuk yang lebih kaya daripada media konvensional.

Multimedia melibatkan perangkat keras dan perangkat lunak. Istilah multimedia identik dengan computer multimedia, yaitu computer yang memiliki kemampuan olah data, olah kata, olah gambar dan olah gerak dimana masing-masing unsur tersebut saling melengkapi, menunjang, dan saling membantu.

Dengan demikian multimedia adalah teknologi yang mengoptimalkan pemanfaatan computer untuk membuat, mengoptimalkan pemanfaatan computer untuk membuat, menampilkan dan merekayasa teks, grafik, audio gambar dengan menggunakan link dan tool yang memungkinkan pemakai untuk bernavigasi, berinteraksi, berkreasi, dan berkomunikasi. Dari sini terkandung ada empat komponen multimedia, yaitu harus ada computer, link alat navigasi, dan tersedianya tempat untuk mengumpulkan, memproses dan mengkomunikasikan informasi. Dengan tampilan yang dapat mengkombinasikan berbagai unsur penyampaian informasi dan pesan, computer dapat dirancang dan digunakan sebagai media teknologi yang efektif.

Komponen Multimedia

Teks

Teks adalah elemen paling awal dan sederhana dalam multimedia, yang biasanya mengacu pada kata, kalimat dan alinea atau segala sesuatu yang tertulis 
atau ditayangkan. Sebagian besar multimedia menggunakan teks sangat efektif untuk menyapaikan ide dan panduan kepada pengguna. Teks merupakan bentuk data multimedia yang paling mudah disimpan dan dikenali, serta file teks merupakan bentuk data multimedia yang paling mudah disimpan dan dikenali, serta file teks merupakan struktur yang sederhana.

Dalam Macromedia Flash, teks diistilahkan dengan tipe yang dapat diberi berbagai efek. Ada 3 jenis teks pada flash yaitu: Static Text Fields: Merupakan teks yang bersifat tetap dan dalam pengoperasiannya tidak akan mengalami perubahan secara dinamis, biasanya digunakan dalam menampilkan informasi. Dynamic Text Fields: Merupakan teks yang menyediakan variable, dalam pengoperasiannya akan mengalami perubahan dinamis, dan untuk menampilkan informasi sesuai dengan variabelnya.Input Teks Fields: Merupakan yang memungkinkan user memberikan masukan teks. Selanjutnya masukan tersebut akan di tindaklanjuti dengan aksi-aksi tertentu sesuai dengan script yang dimasukkan.

Image atau Gambar

Gambar merupakan tampilan diam atau tidak bergerak. Gambar merupakan salah satu komponen penting dalam multimedia karena dapat meringkas dan menyajikan data kompleks serta mampu menyampaikan seribu kata. Gambar dalam publikasi multimedia lebih menarik perhatian dan dapat mengurangi kebosanan dibandingkan dengan teks sebab manusia selalu berorientasi terhadap visual.

Menurut suryanto, format file gambar yang digunakan dalam multimedia yaitu:

a) PICT

Merupakan formate file default Macintosh yang mampu untuk membuat objek yang digambar secara bitmap maupun amper.

b) BMP

Merupakan formate file default Windows. Format ini mendukung RGB, Indexed Colour, Grayscale dan Bitmap colour mode tetapi tidak mendukung alpha cabnnel.

c) JPEG (Joint Photographic Experts Group)

Format grafik yang terkompresi, digunakan d. alam tampilan foto dan gambar secara ampere, dapat mengendalikan kedalaman warna serta mempunyai ukuran yang ampere kecil.

d) GIF (Grafic Interchange File Format)

Format file yang terkompresi yang dikembangkan oleh CompuServe.

e) TIFF (Tagged Interchange File Format)

Format file terkompresi yang digunakan di paket desktop publishing. Kekuatan dari format ini adalah lebih fleksibel dari format gambar bitmap yang didukung secara ritual oleh seluruh point, image editing dan aplikasi kedalaman layout.

f) EPS (Encapsulated Post Script)

Merupakan format file yang digunakan dalam photoshop dapat memuat baik gambar amper maupun grafik.

g) PNG (Portable Network Graphics)

Merupakan format file terkompresi untuk menampilkan gambar pada World Wide Web, mempunyai kamampuan menampilkan gambar 24 bit dan menghasilkan latar belakang secara transparan.

h) PSD 
Merupakan format file yang digunakan photoshop untuk menyimpan file yang dibuat dan dimanipulasi. File PSD tidak dikompresi dan memuat informasi tentang berbagai graphics layer yang ada tanpa sebuah file.

i) Animasi

Animasi merupakan susunan gambar mati yang dibuat efek sehingga seolah-olah tampak bergerak. Perbedaan movie dengan animasi adalah animasi merupakan proses kejadiannya sedangkan movie merupakan prose hasilnya. Menurut hakim dan mutmainah, teknik animasi dalam flash yaitu:

(1) Motion

Animasi pada Flash yang digunakan untuk menggerakkan objek dan satu titik ke titik lain tanpa mengalami perubahan bentuk.

(2) Shape

Animasi pada flash yang digunakan untuk mengubah atau mengganti suatu bentuk dengan bentuk lain.

j) Audio

Sebuah aplikasi multimedia tanpa bunyi hanya disebut unimedia, bukan multimedia. Bunyi dapat ditambahkan dalam produksi multimedia melalui suara, ampere dan efek-efek suara.

Suara dalam computer dapat disimpan dalam berbagai format. Menurut Suryanto, format-format file suara (audio) tersebut antara lain:

(1) MP3 (MPEG Audio Player 3)

(2) File audio yang digunakan suatu codec untuk melakukan encoding dan decoding suatu rekaman music, dengan ekstensi *.mp3.

(3) MIDI (Musical Instrument Digital Interface)

File audio yang digunakan untuk menyimpan instrument music dengan ekstensi *.midi.

(4) DAT (Digtal Audio tape)

Format file yang menggunakan head yang diputar serupa dengan Video Tape Recorder (VTR).

(5) WAV (Waveform Audio)

Merupakan format file audio yang berbentuk digital, dapat dimanipulasi dengan perangkat lunak PC multimedia.

k) Actionscript (Bahasa Pemrograman)

Bahasa pemrograman yang digunakan dalam pembuatan aplikasi ini adalah actionscript ini hampir mirip dengan javascript dalam web. Actionscript berfungsi untuk mengontrol objek dalam Flash, mengatur navigasi dan interaktifitas dengan pengguna. Letak interaktifitas sebuah file Flash terletak pada pemakaian actionscipt.

Menurut Hakim dan Mutmainah action pada flash dibagi menjadi 2, yaitu:

(1) Action Frame

Merupakan action yang diberikan pada frame, frame yang berisi action terdapat tanda pada framenya.

(2) Action Objek

Merupakan action yang diberikan pada objek, baik berupa tombol maupun movie clip.(Mustika et al., 2018) 


\section{Pengertian Macromedia Flash}

Pengenalan Flash

Flash merupakan salah satu teknologi komputasi multimedia. Multimedia diartikan sebagai kombinasi dari teks, grafik, animasi suara dan video yang digabung menjadi satu kesatuan kerja yang menghasilkan suatu informasi yang memiliki nilai komunikasi interaktif yang sangat tinggi bukan hanya dilihat sebagai hasil cekatan melainkan dapat didengar, membentuk simulasi dan animasi yang memiliki seni grafis yang sangat tinggi dalam penyampaian(Lestari et al., 2019).

Macromedia Flash merupakan sebuah program yang didesain khusus oleh macromedia, saat itu sebagai pengembangan yang saat ini sudah dibeli oleh Adobe Incorporated sehingga berubah nama menjadi Adobe Flash. Flash didesain dengan kemampuan untuk membuat animasi 2 dimensi yang handal dan ringan sehingga flash banyak digunakan untuk membangun dan memberikan efek animasi pada website, CD Interaktif dan yang lainnya.

Macromedia Flash 8 merupakan sebuah aplikasi buatan Macromedia. Banyak aplikasi bermanfaat yang diciptakan Macromedia, sebut saja Dreamweaver, Flash, Director, Freehand, dan yang lain sebagainya. Gambar Tampilan Macromedia Flash 8 di tunjukkan pada Gambar 2.1

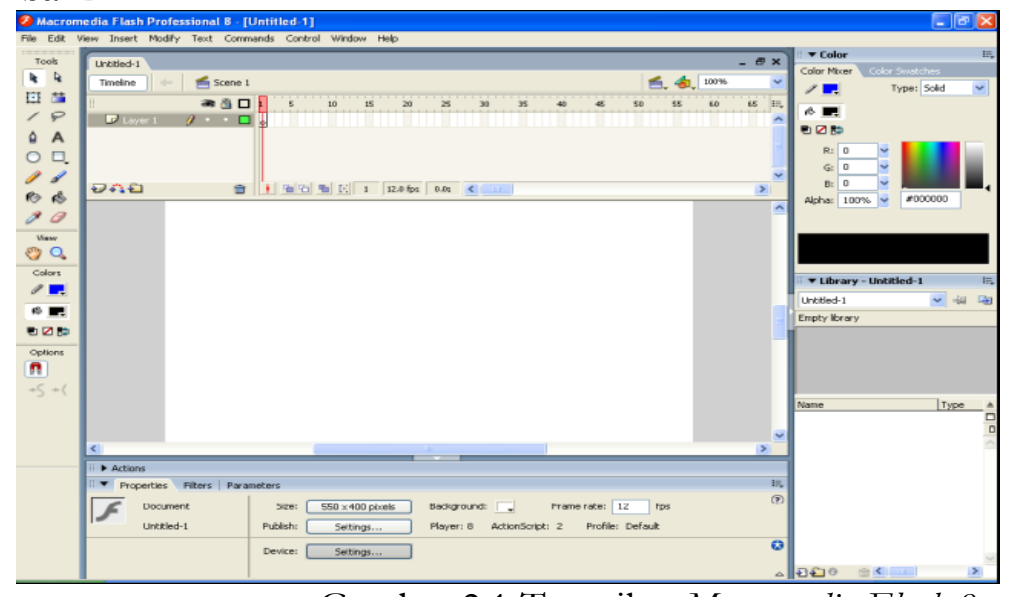

Gambar 2.1 Tampilan Macromedia Flash 8

Bagi seorang desainer, mungkin mereka mengenal dan bahkan menggunakan semua jenis software buatan macromedia ini. Dreamweaver digunakan untuk mendesain sebuah website, director dan flash dapat digunakan dalam perancangan perangkat lunak interaktif dengan navigasi dari desain yang sangat menarik.

Keunggulan yang dimiliki dari Flash yaitu mampu disisipkan sedikit code pemrograman baik yang berjalan secara otomatis untuk mengatur animasi yang ada didalamnya atau digunakan untuk berkomunikasi dengan program lain seperti HTML, PHP, dan Database dangan pendekatan XML.

Panel tools

Komponan flash yang digunakan dalam pembuatan objek dalam aplikasi ini terletak pada panel tools. Adapun komponen-komponen tersebut dapat dilihat di gambar tabel 2.2

\begin{tabular}{lll}
\hline Nama Tool & Ikon & Fungsi \\
\hline Arrow Tool & Untuk memilih objek \\
Sub Select Tool & Untuk mengedit garis \\
\hline
\end{tabular}




\begin{tabular}{l|l}
\hline $\begin{array}{l}\text { Free Transform Tool } \\
\text { Gradient Transform } \\
\text { Tool } \\
\text { Line Tool }\end{array}$ & $\begin{array}{l}\text { Untuk mentransform objek } \\
\text { Untuk mengatur setting gradiasi }\end{array}$ \\
Text Tool & Untuk membuat objek garis \\
Oval Tool & Untuk membuat objek teks \\
Rectangle Tool & Untuk membuat objek lingkaran \\
Pencil Tool & Untuk membuat objek segi empat \\
Ink Bottle & Untuk membuat objek bebas berupa \\
Point Bucket Tool & garis \\
\hline
\end{tabular}

Gambar 2.2 Komponen Macromedia Flash 8

\section{Kemampuan Flash}

Animasi merupakan proses menciptakan efek gerak atau efek perubahan bentuk yang terjadi selama beberapa waktu. Animasi bisa berupa gerak sebuah obyek dari tempat satu ke tempat yang lain, perubahan warna atau perubahan bentuk (yang disebut morphing).

Flash sangat memungkinkan membuat movie yang interaktife sehingga user dapat menggunakan alat-alat input komputer seperti keyboard dan mouse untuk menjalankan bagian movie lain, menggerakkan obyek memasukkan informasi tertentu dan menampilkan beberapa informasi sekaligus.

\section{Flash Player}

Flash Player adalah software untuk melihat animasi dan movie dngan menggunakan computer. Flash player menjalankan file SWF. Apabila menginginkan software Macromedia flash versi apa saja maka akan disertai Flash Player didalam.

\section{Struktur Navigasi}

Struktur Navigasi merupakan alat bantu untuk meranang aliran aplikasi multimedia. Ada beberapa cara yang digunakan untuk mendesain aliran aplikasi multimedia diantaranya adalah struktur linier, struktur menu, struktur bierarki, stuktur jaringan dan struktur kombinasi.

Struktur linear: Struktur linear adalah struktur navigasi yang paling sederhana. Dalam menampilkan aplikasi multimedia terdapat dua menu yakni maju (next) dan mundur (back). Skema dari struktur linear dapat dilihat di Gambar 2.3

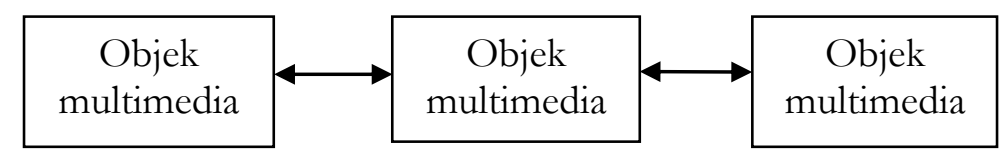

Gambar 2.3 Struktur Linear

Struktur Menu: Struktur menu berbentuk garis-garis hypertext, gambar, audio, video dan animasi atau kombinasi dari semua objek tersebut. Skema struktur menu dapat dilihat pada gambar2. 4 . 


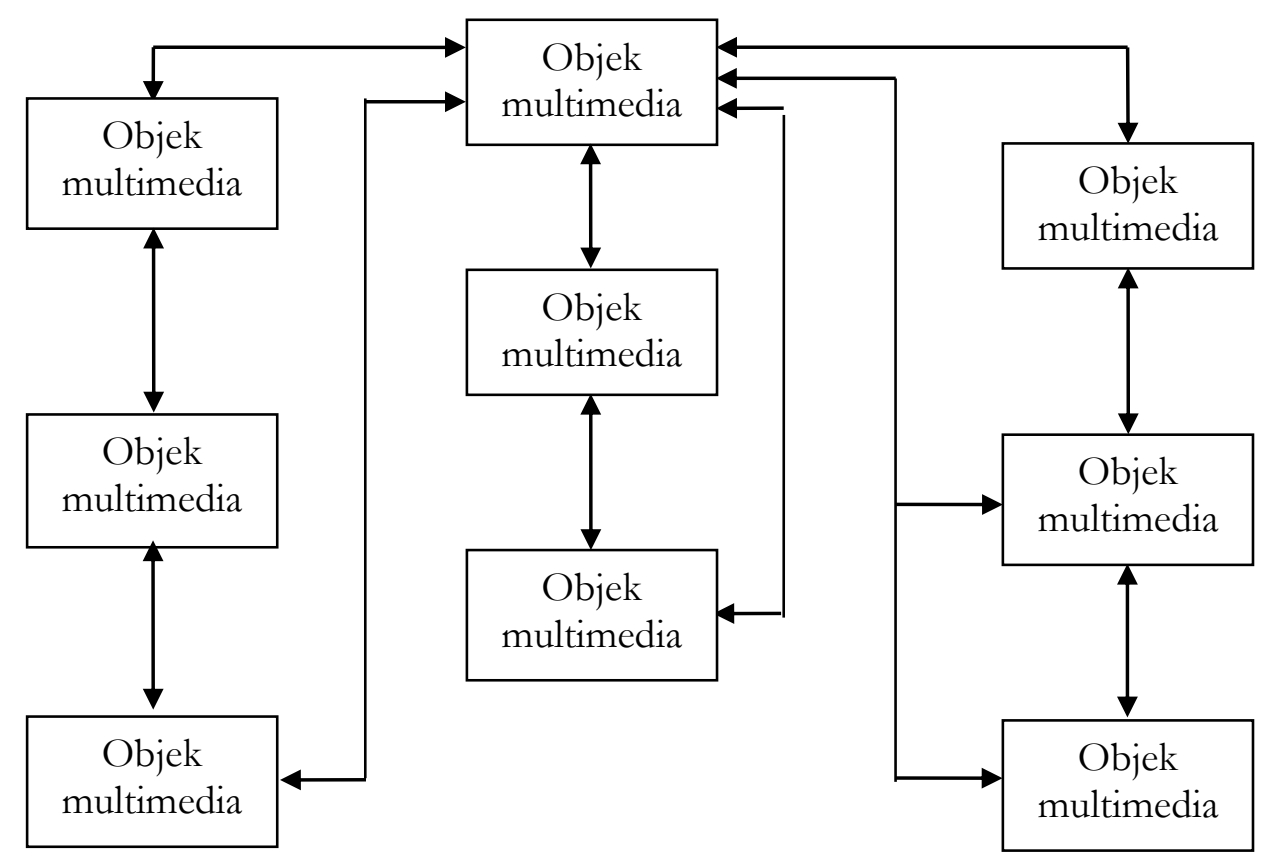

Struktur Hierarki

Gambar 2.4 Struktur Menu

Struktur hierarki berbentuk seperti tangga atau pohon, dimana masing-masing objek menyediakan sebuah menu pilihan yang memiliki lebih banyak menu dengan lebih banyak pilihan. Tidak ada batas jumlah pilihan dalam sebuah struktur hierarki dapat dilihat pada gambar 2.5

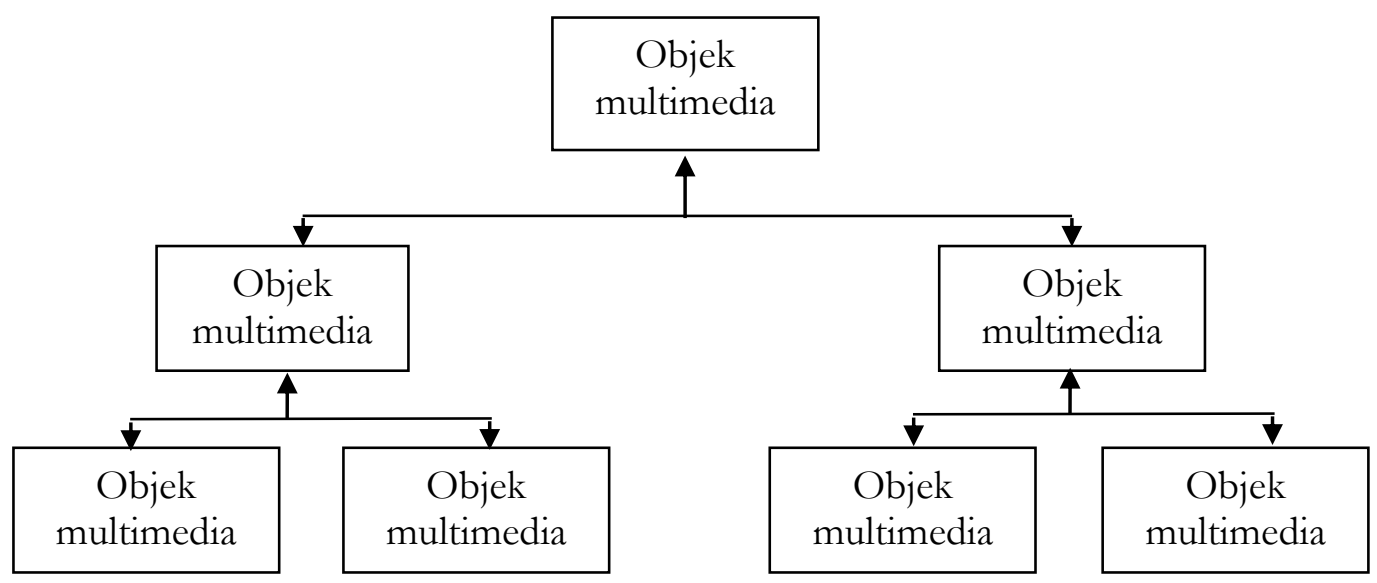

Struktur Jaringan

Gambar 2.5 Struktur Hierarki

Struktur jaringan merupakan desain yang paling kompleks dengan banyak objke dalam setiap arah pada setiap objek dalam aplikasi multimedia. Skema struktur jaringan dapat dilihat pada gambar 2.6 


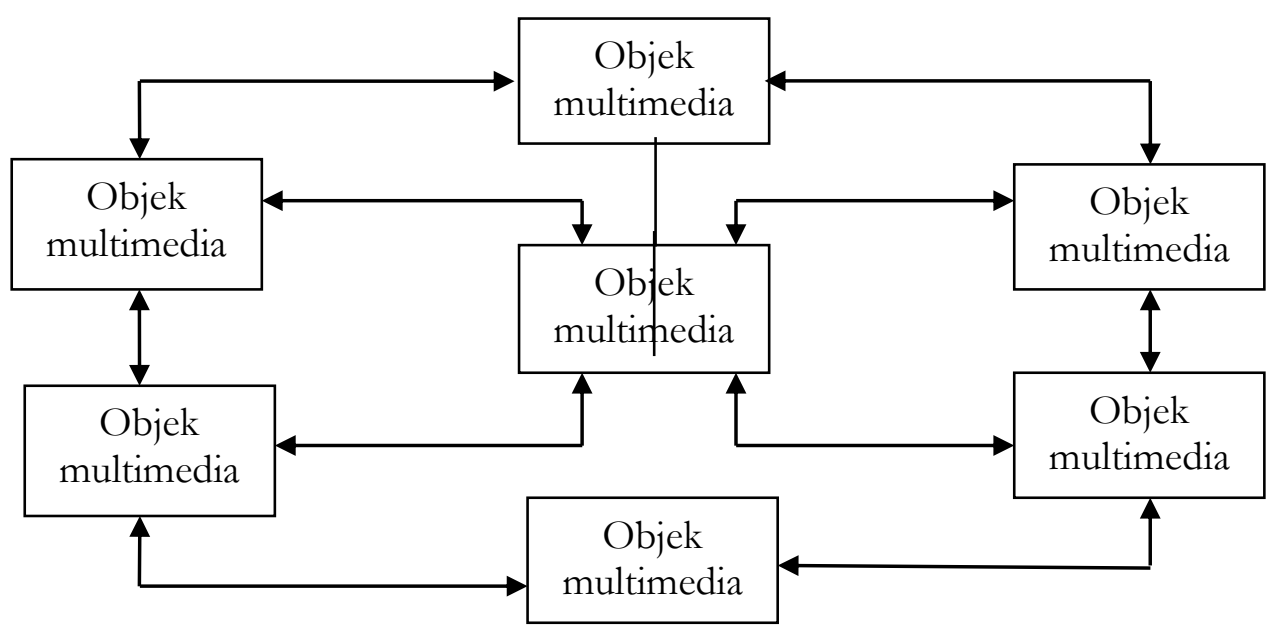

Gambar 2.6 Struktur Jaringan

Struktur kombinasi

Struktur kombinasi adalah struktur navigasi yang mengkombinasikan strukturstruktur yang ada. Skema dari struktur kombinasi dapat dilihat pada gambar 2.7

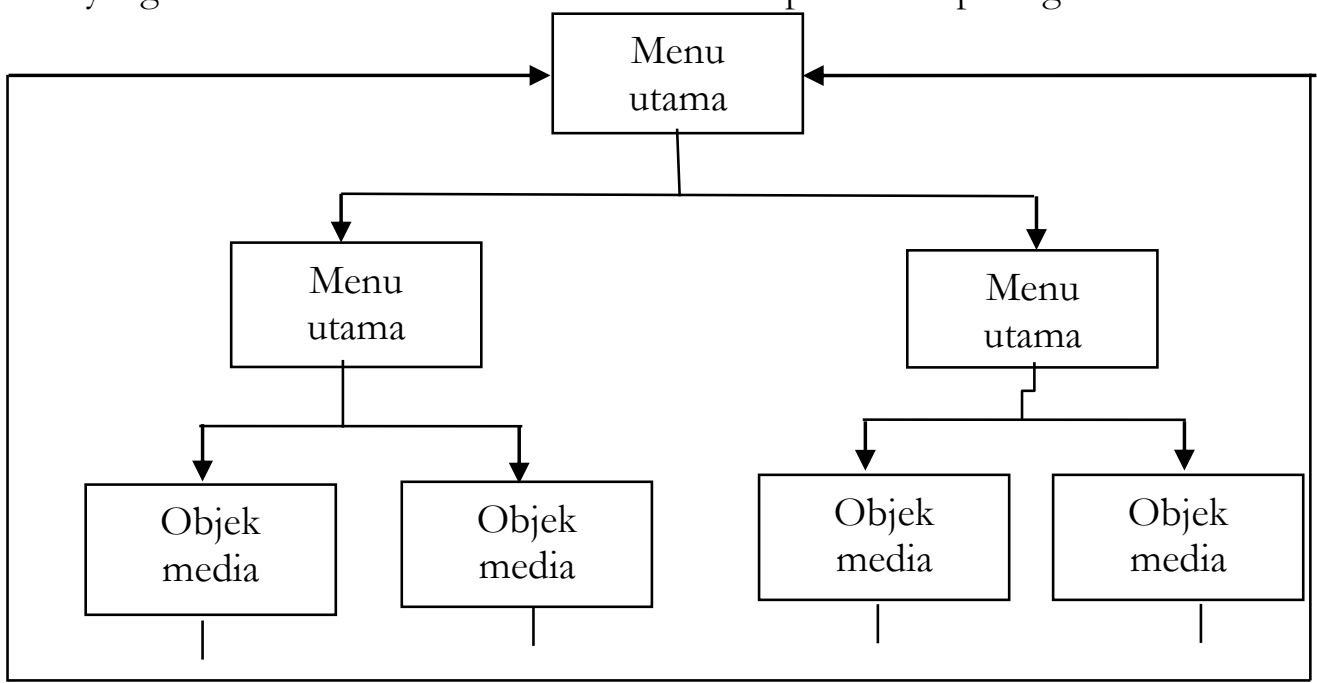

\section{Pengertian Pendidikan Agama Islam}

Pengertian pendidikan agama Islam itu bermacam-macam, hal ini disebabkan karena perbedaan falsafah hidup yang dianut dan sudut pandang yang memberikan rumusan tentang pendidikan itu (Aprilianto \& Arif, 2019; Muslimin \& Kartiko, 2020). Syariat Islam tidak akan dihayati dan diamalkan orang kalau hanya diajarkan saja, tetapi harus dididik melalui proses pendidikan Nabi sesuai ajaran Islam dengan berbagai metode dan pendekatan dari satu segi kita lihat bahwa pendidikan Islam itu lebih banyak ditujukan kepada perbaikan sikap mental yang akan terwujud dalam amal perbuatan baik bagi keperluan diri sendiri maupun orang lain. Dari segi lainnya, pendidikan Islam tidak bersifat teoritis saja, tetapi juga praktis. Ajaran Islam tidak memisahkan antara iman dan amal shaleh. Oleh karena itu, pendidikan Islam adalah sekaligus pendidikan iman dan pendidikan amal dan juga karena ajaran Islam berisi tentang ajaran sikap dan tingkah laku pribadi masyarakat menuju kesejahteraan hidup perorangan dan bersama, maka pendidikan Islam adalah pendidikan individu dan pendidikan masyarakat. Semula yang bertugas mendidik adalah para Nabi dan Rasul selanjutnya para ulama, dan cerdik pandailah sebagai penerus tugas, dan kewajiban mereka (Setiawan, 2019) 
Ahmad Tafsir mendefenisikan pendidikan Islam sebagai bimbingan yang diberikan oleh seseorang agar ia berkembang secara maksimal sesuai dengan ajaran Islam. Bila disingkat pendidikan Islam ialah bimbingan terhadap seseorang agar ia menjadi muslim semaksimal mungkin(Kusumawardhani \& Malang, 2020)

Berdasarkan uraian di atas, dapat disiimpulkan bahwa pendidikan agama Islam adalah kegiatan yang dilakukan untuk membimbing sekaligus mengarahkan anak didik menuju terbentuknya pribadi yang utama berdasarkan nilai-nilai etika Islam dengan tetap memelihara hubungan baik terhadap Allah Swt, sesama manusia, dirinya sendiri dan alam sekitarnya.

\section{Tujuan Pendidikan Agama Islam}

Zakiah Daradjat dalam Metodologi Pengajaran Agama Islam mendefinisikan tujuan Pendidikan Agama Islam yaitu kepribadian muslim, yaitu suatu kepribadian yang seluruh aspeknya dijiwai oleh ajaran Islam. Karena itu pendidikan Islam berarti juga pembentukan manusia yang bertakwa, ini sesuai benar dengan pendidikan nasional yang akan membentuk manusia pancasila yang bertakwa kepada Tuhan Yang Maha Esa (Konsep Pendidikan Islam Dalam Keluarga Menurut Prof. Dr. Zakiyah Darajat, n.d.)

Tujuan pendidikan Islam yaitu manusia yang berguna bagi dirinya dan masyarakatnya serta senang dan gemar mengamalkan dan mengembangkan ajaran Islam dalam berhubungan dengan ajaran Allah dan dengan manusia sesamanya, dapat mengambil manfaat yang semakin meningkat dari alam semesta ini untuk kepentingan hidup di dunia kini dan di akhirat nanti(Batubara \& Ariani, 2019)

Berdasarkan uraian diatas tujuan pendidikan agama Islam adalah membentuk manusia yang bertakwa pada Allah SWT, mampu berhubungan baik dengan sesama manusia dan berhubungan baik dengan alam sekitarnya.

\section{Fungsi Pendidikan Agama Islam}

Fungsi pendidikan Islam menurut Kurshid Ahmad adalah sebagai berikut :

a. Alat untuk memelihara, memperluas dan menghubungkan tingkat-tingkat kebudayaan, nilai-nilai tradisi dan sosial, serta ide - ide masyarakat dan bangsa.

b. Alat untuk mengadakan perubahan, inovasi dan perkembangan yang secara garis besarnya melalui pengetahuan dan skill yang baru ditemukan, dan melatih tenaga tenaga manusia yang produktif untuk menemukan perimbangan perubahan sosial dan ekonomi(Ismanto et al., 2014)

Fungsi pendidikan Islam, dijelaskan dalam Al-Qur'an surat Al Baqarah ayat 151:

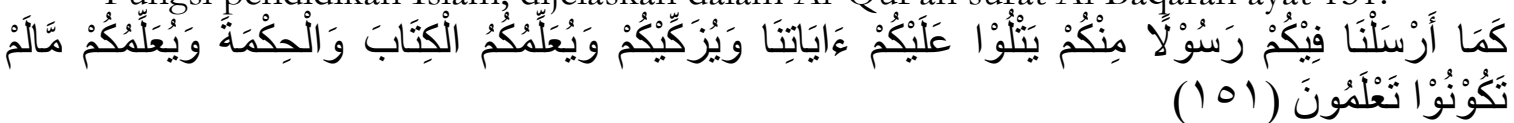

Artinya "Sebagaimana kami telah mengutus kepada kamu sekalian seorang rasul diantara kau yang membacakan ayat-ayat kami kepadamu, menyucikan mu, mengajarkan al-Kitab, dan al-bikmah, dan mengajarkan kepadamu yang belum kamu ketahui"(QS. Al-Baqarah : 151).

\section{Ruang Lingkup Pendidikan Agama Islam}

Ruang lingkup Pendidikan Agama Islam meliputi keserasian, keselarasan, dan keseimbangan antara hubungan manusia dengan Allah SWT, hubungan manusia dengan sesama manusia, dan ketiga hubungan manusia dengan dirinya sendiri, serta hubungan manusia dengan makhluk lain dan lingkungannya.

Ajaran yang dibawa Nabi Muhammad dari Allah ini berisi pedoman pokok yang mengatur hubungan manusia dengan Tuhannya (Allah), dengan dirinya sendiri, dengan manusia sesamanya, dengan makhluk bernyawa yang lainnya, dengan benda mati dan alam semesta ini (Sundari, 2021). Karena agama Islam ini memuat ajaran tentang tata hidup yang berisi pedoman pokok yang yang akan digunakan oleh manusia dalam menjalani kehidupannya di dunia ini dan untuk menyiapkan kehidupan yang sejahtera di akhirat nanti. 
Dengan demikian berarti bahwa ruang lingkup pengajaran agama islam itu luas sekali meliputi seluruh aspek kehidupan(Ismanto et al., 2014).

Apabila dilihat dari segi pembahasannya maka ruang lingkup Pendidikan Agama Islam yang umum dilaksanakan di sekolah adalah :

a. Al-Qur'an dan Hadist

Al-Qur'an dan Hadist adalah sumber pokok ajaran-ajaran dalam agama Islam. Tujuan manusia adalah mencari kebahagiaan baik di dunia dan akherat, dan di dalam alQur'an dan Hadist itu terdapat petunjuk untuk mencapai kebahagiaan tersebut.

b. Aqidah

Adapun yang dimaksud dengan Aqidah Islam adalah kepercayaan yang mantap kepada Allah, para malaikat-Nya, kitab-kitab suci-Nya, para rasul-Nya, hari akhir, qadar yang baik dan buruk, serta seluruh muatan al-Qur'an al-Karim dan al-Sunnah alShohihah berupa pokok-pokok agama(Hasan, 2010). Bisa diambil kesimpulan bahwa Aqidah Islam adalah kepercayaan yang harus diakui orangmukmin tentang kebenarannya berdasarkan dalil aqli dan juga dalil naqli.

c. Akhlak

Akhlak ini mempunyai hubungan yang erat dengan aqidah, yang sudah kita bahas sebelumnya. Adanya hubungan ini dikarenakan aqidah adalah gudang akhlaq yang kokoh. Akhlaq mampu menciptakan kesadaran diri bagi manusia untuk berpegang teguh kepada norma dan nilai-nilai akhlaq yang luhur(Muchith, 2016).

d. Fiqih

Kata "fiqh" secara etimologis berarti faham yang mendalam. Secara definitif, fiqih berarti ilmu tentang bukum-bukum syar'i yang bersifat amaliah yang digali dan ditemukan dari dalil-dalil yang tafsili. Sedangkan al-Amidi memberikan definisi fiqih yang berbeda yaitu ilmu tentang seperangkat bukum-bukum syara' yang bersifat furn'iyyah yang berhasil didapatkan melalui penalaran dan istidlal.

Dari kedua definisi di atas dapat ditemukan bahwa fiqih adalah:

1) Ilmu tentang hukum Allah

2) Yang dibicarakan adalah hal-hal yang bersifat 'amaliyyah- furu'iyyah;

3) Pengetahuan tentang hukum Allah itu didasarkan pada dalil tafsili;

4) Fiqih itu digali dan ditemukan melalui penalaran dan istidlal seorang mujtahid atau faqih;

Dengan demikian, secara ringkas dapat dikatakan fiqih adalah dugaan kuat yang dicapai seorang mujtabid dalam usahanya menemukan bukum Allab(Hasan, 2010)

e. Tarikh dan kebudayaan Islam

Tarikh dan kebudayaan Islam meliputi sejarah arab pra-Islam; kebangkitan Nabi yang di dalamnya menjelaskan keberadaan Nabi sebagai pembawa risalah; pengaruh Islam dikalangan bangsa Arab; Khulafaur Rasyidin; berdirinya Daulah Amawiyah; pergerakan politik dan agama serta berbagai motifnya yang sangat berpengaruh terhadap politik, agama, kesusastraan, kemasyarakatan, dan lain-lain; kebudayaan dan seni(Annisa et al., 2019).

\section{Kajian Teori dalam Perspektif Islam}

Sebelum Membahas media pembelajaran, penulis akan membedakan dengan media/alat pendidikan dengan media pembelajaran. yang akan dibahas kali ini adalah media pembelajaran yang merupakan bagian dari media/alat pendidikan, karena media pembelajaran merupakan salah satu bagian besar dari dua bagian media pendidikan. media/ alat pendidikan meliputi dua macam yaitu: 1 . Perbuatan pendidik (biasa disebut software atau immaterial); mencakup nasehat, teladan, larangan, perintah, pujian, teguran, ancaman dan hukuman. 2. Benda-benda sebagai alat bantu (bisa disebut hardware atau material); mencakup meja kursi belajar, papan tulis, penghapus, kapur tulis, buku, peta, OHP, dan 
sebagainya(Mustika et al., 2018) Dengan demikian, fokus uraian media pembelajaran ini pada bagian kedua dari alat pendidikan. Beberapa jenis media pembelajaran yang dinyatakan dalam Alquran dan Hadis, sebagai berikut:

Media Pembelajaran Audio. Media pembelajaran audio adalah media yang hanya dapat didengar, berupa suara dengan pelbagai alat penyampai suara baik dari manusia maupun immanusia.(Taufiq Ari Nugroho \& ., 2019). Dalil yang berhubungan dengan suara sebagai sumber penyampai pesan, dapat diambil dari kata baca, menjelaskan, ceritakan, dan kata-kata lain yang semakna. Dalam hal ini terdapat beberapa ayat yang memberikan keterangan adanya media pembelajaran audio di dalam Al-qur'an, diantaranya surah Al-Isrā' (17) ayat 14:

"Bacalah kitabmu, cukuplah dirimu sendiri pada waktu ini sebagai penghisab terhadapmu”. Kata lain yang mengisyaratkan penggunaan media audio adalah menjelaskan (asal kata kerja "jelas"), di antaranya terdapat dalam surah Al-Tawbah (9); 11:

"Jika mereka bertaubat, mendirikan salat dan menunaikan zakat, maka (mereka itu) adalah saudara- saudaramu seagama. dan Kami menjelaskan ayat-ayat itu bagi kaum yang mengetahui."

Kata lain yang mengisyaratkan penggunaan media audio adalah ceritakan (asal kata "cerita"), di antaranya terdapat dalam surah Al- Baqarah (2); 76:

"... lalu mereka berkata: "Apakah kamu menceritakan kepada mereka (orang-orang mukmin) apa yang telah diterangkan Allah kepadamu, supaya dengan demikian mereka dapat mengalabkan bujjahmu di hadapan Tubanmu; tidakkah kamu mengerti?"(QS. Al-Baqarah: 76)

Dari kata kerja "bacalah, menjelaskan, dan ceritakan", di atas tentunya akan menimbulkan bunyi atau suara sehingga dapat dipahami apa isi yang disampaikan, dan mungkin juga terdapat guru yang menyampaikan bahan pembelajaran dengan hanya membacakan buku/kitab yang dijadikan rujukan dalam suatu pembelajaran (Rofi'ah, 2020; Tajudin \& Aprilianto, 2020). Namun yang lebih ditekankan dari kata baca, menjelaskan, dan ceritakan adalah timbulnya suara yang dapat menyampaikan bahan pembelajaran. Pada perkembangan selanjutnya media audio dikembangkan dengan pelbagai alat audio, seperti:

Radio, merupakan perlengkapan elektronik yang dapat digunakan untuk mendengarkan berita yang bagus dan aktual, dapat mengetahui beberapa kejadian dan peristiwa- peristiwa penting dan baru, masalah-masalah kehidupan dan sebagainya. Radio dapat digunakan sebagai media pembelajaran yang cukup efektif (Rony \& Jariyah, 2020; Sj et al., 2021).

Hubungan media audio ini dengan tujuan pembelajaran pendidikan agama Islam sangat erat. Dari sisi kognitif, media audio ini dapat dipergunakan untuk mengajarkan pelbagai aturan dan prinsip. Dari segi afektif, media audio ini dapat menciptakan suasana pembelajaran, dan segi psikomotor media audio ini untuk mengajarkan media keterampilan verbal. Sebagai media yang bersifat auditif, maka media ini berhubungan erat dengan radio, alat perekam pita magnetik, piringan hitam, atau mungkin laboratorium bahasa.(Nasir, 2020).

\section{Teknik Analisis}

Data yang diperoleh melalui instrumen penilaian pada saat uji coba dianalisis dengan menggunakan statistik deskriptif kualitatif. Analisis ini dimaksudkan untuk menggambarkan karakteristik data pada masing-masing variabel. Dengan cara ini diharapkan akan mempermudah memahami data untuk proses analisis selanjutnya. Hasil analisis data digunakan sebagai dasar untuk merevisi produk media yang dikembangkan(Suharsimi, 2006).

Data yang terkumpul diproses dengan cara dijumlahkan, dibandingkan dengan jumlah yang diharapkan dan diperoleh persentase atau dapat ditulis dengan rumus sebagai berikut(Suharsimi, 2006). 


\section{PRESENTASE KELAYAKAN $=\frac{\text { Skor yang diobservasi }}{\text { Skor yang diharapkan }} \times 100 \%$}

Data yang terkumpul dianalisis dengan teknik analisis deskriptif kuantitatif yang diungkapkan dalam distribusi skor dan persentase terhadap kategori skala penilaian yang telah ditentukan. Setelah penyajian dalam bentuk persentase, langkah selanjutnya mendeskriptifkan dan mengambil kesimpulan tentang masing-masing indikator. Kesesuaian aspek dalam pengembangan bahan ajar dan media pembelajaran dapat menggunakan tabel berikut.

Tabel 3.3 Tabel skala persentase menurut Arikunto. ${ }^{2}$ Persentase Pencapaian

Interpretasi

\begin{tabular}{ll}
\hline $81-100 \%$ & Sangat Layak \\
$\mathbf{6 1 - 8 0 \%}$ & Layak \\
$\mathbf{4 1 - 6 0 \%}$ & cukup layak \\
$\mathbf{2 1 - 4 0 \%}$ & kurang layak \\
$\mathbf{0 - 2 0 \%}$ & tidak layak
\end{tabular}

Pada tabel 3.3 di atas digunakan sebagai acuan penilaian untuk mengetahui kelayakan produk.

Analisis kepraktisan dalam penelitian ini ditinjau dari dua indikator, yaitu:

a. analisis respon guru

b. analisis respon peserta didik.

Hal tersebut dapat dijelaskan sebagai berikut:

a. Analisis Respon Guru

Analisis data respon guru dilakukan dengan langsung mendeskripsikan apa adanya jawaban dari guru yang diwawancarai untuk menggambarkan kesan atau penilaian guru terhadap media pembelajaran yang telah dikembangkan. Selanjutnya, data tentang respons guru terhadap media pembelajaran menggunakan macromedia flash pada materi Sholat dan Zakat dianalisis dengan persentase. Persentase respon guru dianalisis dengan menggunakan rumus sebagai berikut.

$$
\begin{array}{ll}
\text { Jarak Interval }= & \frac{\text { Skor Tertinggi }- \text { Skor Terendah }}{\text { Jumlah Kelas Interval }} \\
\text { skor tertinggi } & =1 \times 20=20 \\
\text { skor terendah } & =0 \times 20=0 \\
\text { kelas interval } & =4
\end{array}
$$

$$
\begin{aligned}
\text { Jarak Interval } & =\frac{20-0}{4} \\
& =5
\end{aligned}
$$

Analisis indikator respon guru dengan jarak interval 20 sebagai berikut.

Tabel 3.4 Kriteria Indikator Respon Guru

\begin{tabular}{clll}
\hline \multicolumn{3}{c}{ Skor Antara $(\mathrm{Sa})$} & Kriteria \\
\hline $\mathbf{1 5}$ & $\leq \mathrm{Sa} \leq$ & Sangat Baik \\
$\mathbf{1 0} \leq \mathrm{Sa}<$ & 15 & Baik \\
$\mathbf{5} \leq \mathrm{Sa}<$ & 10 & Cukup \\
$\mathbf{1}$ & $\leq \mathrm{Sa}<\quad 5$ & Jelek \\
\hline
\end{tabular}


b. Analisis Respons Peserta didik

Analisis data respon peserta didik yang diperoleh melalui angket dianalisis secara deskriptif menggunakan persentase. Analisis respon peserta didik untuk mengetahui respon atau tidaknya terhadap proses pembelajaran menggunakan macromedia flash mata pelajaran fiqh bab Sholat dan Zakat. Respon dihitung dengan rumus sebagai berikut. ${ }^{3}$

$$
\begin{aligned}
& \text { Jarak Interval }=\frac{\text { Skor Tertinggi }- \text { Skor Terendah }}{\text { Jumlah Kelas Interval }} \\
& \text { skor tertinggi } \quad=1 \times 24=24 \\
& \text { skor terendah } \quad=0 \times 24=0 \\
& \text { kelas interval } \quad=4 \\
& \text { Jarak Interval }=\frac{24-0}{4} \\
& =6
\end{aligned}
$$

Tabel 3.5 Kriteria Indikator Respon Peserta didik

\begin{tabular}{llll} 
& \multicolumn{2}{c}{ Skor Antara $(\mathrm{Sa})$} & Kriteria \\
\hline $\mathbf{1 9}$ & $\leq \mathrm{Sa} \leq \quad 24$ & Sangat Baik \\
$\mathbf{1 3}$ & $\leq \mathrm{Sa}<$ & 18 & Baik \\
$\mathbf{7}$ & $\leq \mathrm{Sa}<\quad 12$ & Cukup \\
$\mathbf{0}$ & $\leq \mathrm{Sa}<\quad ;$ & Jelek \\
\hline
\end{tabular}

Analisis indikator respon peserta didik dapat dihitung dengan rumus sebagai berikut.

$$
\begin{aligned}
\text { Jarak Interval } & =\frac{\text { Skor Tertinggi }- \text { Skor Terendah }}{\text { Jumlah Kelas Interval }} \\
\text { skor tertinggi } & =1 \times 100=100 \\
\text { skor terendah } & =0 \times 100=0 \\
\text { kelas interval } & =4 \\
\text { Jarak Interval } & =\frac{100-0}{4} \\
& =25
\end{aligned}
$$

Analisis indikator aktivitas peserta didik dengan jarak interval 2,5 sebagai berikut.

Tabel 3.6 Kriteria Indikator Respon Aktivitas Peserta Didik

\begin{tabular}{llll}
\hline \multicolumn{2}{c}{ Skor } & Antara $(\mathrm{Sa})$ & \multicolumn{3}{c}{ Kriteria } \\
\hline $\mathbf{7 5}$ & $\leq \mathrm{Sa} \leq$ & 100 & Sangat Baik \\
$\mathbf{5 0}$ & $\leq \mathrm{Sa}<$ & 75 & Baik \\
$\mathbf{2 5}$ & $\leq \mathrm{Sa}<$ & 50 & Cukup \\
$\mathbf{0}$ & $\leq \mathrm{Sa}<$ & 25 & Jelek \\
\hline
\end{tabular}

\section{Hasil Pembahasan}

Hasil pengembangan software media pembelajaran dalam pembelajaran Fiqih materi pokok sholat dan zakat kelas VIII SMP berupa software media pembelajaran yang dikemas dalam Compact Disc (CD). Beberapa tahapan yang dilakukan dalam pengembangan software yaitu : 
Hasil analisis tahap perancangan media pembelajaran ini dibagi dalam dua tahap, yaitu tahap analisis spesifikasi teknis dan tahap analisis kerja program. Tahap analisis spesifikasi teknis untuk mengetahui persyaratan minimal sebuah personal computer (PC) untuk dapat menjalankan media pembelajaran berbasis komputer. Sedangkan tahap analisis kerja program dilakukan untuk mengetahui kinerja dari media pembelajaran berbasis komputer yang telah dibuat.

a. Analisis Spesifikasi Teknis

Untuk menjalankan software ini diperlukan spesifikasi hardware dan software. Alat yang digunakan sebagai berikut:

1) Hardware

(1) Seperangkat komputer dengan spesisfikasi:

Processor : : AMD A6-6310 APU with AMD Radeon R4

Graphics $: 1.80 \mathrm{GHz}$

Memory :2 GB

Resolusi : $1024 \times 768$

Harddisk : $80 \mathrm{~Gb}$

OS : Microsoft Windows 8.1 Single Language with Bing

(2) CD Blank

(3) CD Room

(4) Mouse dan Keyboard

(5) Speaker

(6) Software

(7) Macromedia Flash professional 8

Merupakan software utama dalam pembuatan aplikasi ini. Software ini dapat menampilkan gabungan antara grafik, suara, teks, animasi, yang akan disimpan menjadi *fla

(8) Corel Draw 17

Digunakan untuk membuat, mengedit dan mengelola gambar yang berhubungan dengan aplikasi ini.

(9) Format Factory

(10) Digunakan untuk mengubah format file (Image, Vidio dan Audio) yang berhubungan dengan aplikasi ini.

(11) Nero Burning Room

Digunakan untuk memasukkan aplikasi ini ke dalam CD (Compact Disk)

\section{Desain Program}

Dari tahapan analisis maka dihasilkan gambaran umum dan konsep media pembelajaran yang dituangkan dalam bentuk flowchart dan storyboard. Konsep dari media ini adalah pengguna akan mendapatkan materi pelajaran yang disampaikan melalui media pembelajaran berbasis multimedia menggunakan macromedia flash dalam pembelajaran Fiqih materi pokok sholat dan zakat kelas VIII SMP.

Setelah materi pembalajaran disusun maka proses yang selanjutnya dilakukan adalah desain program. Desain program adalah langkah kedua dalam fase pengembangan media pembelajaran berbasis komputer. Tahap-tahap desain media adalah sebagai berikut:

a. Diagram Alir (Flowchart)

Diagram alir program merupakan bagan dengan simbol-simbol tertentu yang menggambarkan urutan proses dan hubungan antara proses secara mendetail dalam suatu program. Diagram alir program digunakan untuk menggambarkan tiap-tiap langkah di dalam program komputer secara logika. Diagram alir dari media pembelajaran yang dikembangkan adalah 
Gambar 4.1 Diagram Alir (Flowchart)

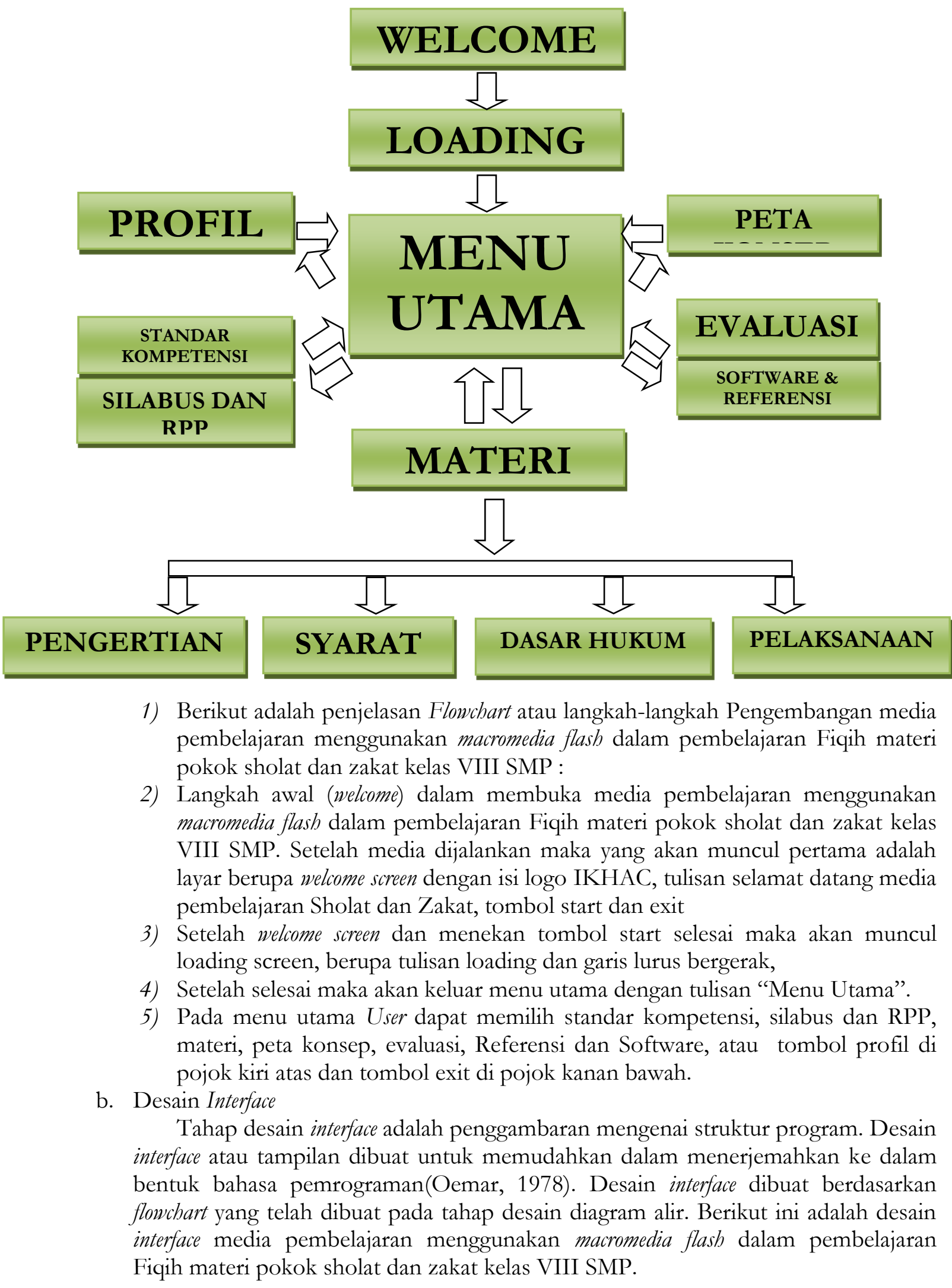




\section{KESIMPULAN}

Berdasarkan tahapan penelitian dan pembahasan yang telah dilakukan. Penulis dapat menarik kesimpulan. Pengembangan media pembelajaran berbasis multimedia menggunakan macromedia flash ini memerlukan beberapa tahapan, yaitu: Mengambil keputusan (decide), membuat disain (design), mengembangkan produk (develop), evaluasi (evaluate). Berdasarkan hasil kevalidan penelitian yang telah dilakukan segabai evaluasi produk yang dikembangkan, bahwa produk yang telah dilakukan revisi sebelum diuji cobakan kepada responden hasil yang didapat dari validasi dari Ahli Materi dengan penilaian aspek pembelajaran memperoleh skor total 69 dengan rerata 4,6 maka bisa dikriteriakan sangat baik atau valid. Validasi dari Ahli Materi dengan penilaian aspek isi memperoleh skor total 67 dengan rerata 4,46 maka bisa dikriteriakan baik atau valid. Validasi dari Ahli Media dengan penilaian aspek Tampilan memperoleh skor total 64 dengan rerata 4,26 maka bisa dikriteriakan baik atau valid. Validasi dari Ahli Media dengan penilaian aspek pemrograman memperoleh skor total 62 dengan rerata 4,13 maka bisa dikriteriakan baik atau valid. Dari data yang diperoleh dan dipaparkan di BAB IV terkait pembelajaran menggunakan Macromedia Flash untuk pembelajaran Fiqih materi pokok Sholat dan Zakat sangat efektif terbukti dengan adanya: Kenaikan rerata nilai pre test dan post test yang telah dilakukan responden dari satu kali pembelajaran, yaitu terdapat kenaikan sebesar 32,285714286 dari 54,571428571 menjadi 86,857142857. Terdapat respon positif peserta didik terhadap pengembangan media menggunakan Macromedia flash yaitu $79 \%$ peserta didik mengategorikan sangat baik, $13 \%$ peserta didik mengategorikan baik dan $8 \%$ peserta didik mengategorikan cukup Penelitian ini memiliki kelebihan dan kekurangan baik dalam proses maupun dalam hal pengembangannya.

Berikut ini beberapa kelebihannya :Memudahkan guru dalam memberikan materi kepada peserta didik, dengan suasana yang lebih interaktif dan menarik, Merupakan media pembelajaran yang sangat mudah pengaplikasiannya / penggunaanya, Memberikan suasana pembelajaran yang sangat menyenangkan.

Berikut ini beberapa kekurangannya: Vidio yang terkadang tidak dapat diputar ketika finishing produk pembelajaran, harus menggunakan beberapa perangkat tambahan (laptop, PC atau komputer, proyektor dan lainnya), program yang digunakan masih menggunakan Macromedia Flash 8 padahal sekarang sudah ada versi Adobe Flash CS6 yang lebih baru, hal ini dikarenakan komputer yang digunakan kurang memadai. Keterbatasan alat produksi, seperti jumlah perangkat, spesifikasi, dan kelengkapan asesoris komputer sehingga produk ini belum bisa dikembangkan secara optimal, Kurangnya pengetahuan tentang Macromedia Flash 8, hal ini karena terbatasnya sumber referensi, pemahaman, dan pengalaman pengembang dalam bahasa pemrograman, Masih bersifat offline sehingga belum bisa diakses secara massal.

Solusi kekurangan pembelajaran menggunakan Macromedia Flash yakni, vidio menggunakan format FLV, menyediakan terlebih dahulu perangkat yang dibutuhkan, menggunakan Software yang lebih baru lagi, mengadakan perangkat yang diperlukan, mempelajari lebih dalam lagi tentang Software yang digunakan untuk pengembangan, diupload dalam format rar beserta aplikasi (Software) agar dapat di download dan digunakan oleh masyarakat umum (khuususnya pendidik). 


\section{REFERENCES}

Amalia, N. R. (2020). Pengembangan Media Pembelajaran Berbasis Multimedia pada Mata Kuliah Konstruksi Bangunan I. Jurnal PenSil. https://doi.org/10.21009/jpensil.v9i2.15350

Annisa, N., Saragih, A. H., \& Mursid, R. (2019). PENGEMBANGAN MEDIA PEMBELAJARAN INTERAKTIF PADA MATA PELAJARAN BAHASA INGGRIS. JURNAL TEKNOLOGI INFORMASI \& KOMUNIKASI DALAM PENDIDIKAN. https://doi.org/10.24114/jtikp.v5i2.12599

Aprilianto, A., \& Arif, M. (2019). Pendidikan Islam dan Tantangan Multikultural: Tinjauan Filosofis. Naz̧hruna: Jurnal Pendidikan Islam, 2(2), 279-289. https://doi.org/10.31538/nzh.v2i2.339

Barkah, H., \& Zakiah, Q. Y. (2017). MANAJEMEN TENAGA PENDIDIK DI MADRASAH. Jurnal Isema : Islamic Educational Management. https://doi.org/10.15575/isema.v2i2.4998

Batubara, H. H., \& Ariani, D. N. (2019). MODEL PENGEMBANGAN MEDIA PEMBELAJARAN ADAPTIF DI SEKOLAH DASAR. Muallimuna: Jumal Madrasah Ibtidaiyah. https://doi.org/10.31602/muallimuna.v5i1.2356

Deni Darmawan dan kunkun Nur Fauzi. (2016). Sistem Informasi Manajemen. PT. Remaja Rosda Karya.

Hakim, L. (2018). PENGEMBANGAN MEDIA PEMBELAJARAN PAI BERBASIS AUGMENTED REALITY. Lentera Pendidikan: Jurnal Ilmu Tarbiyah Dan Keguruan. https://doi.org/10.24252/lp.2018v21n1i6

Hasan, I. (2010). Relevansi pemikiran pendidikan al-ghazali di tengah idiologi pendidikan dewasa ini. Islamadina.

Ismanto, H. S., Sulianto, J., Sary, R. M., Habibah, S., Kardiyah, Munawar Rahmat, U. S., Talib, N. H. F., Saleh, N. A. M., Badli, N. M., Rizkiani, A., Selatan, T., Dan Budaya Religius Sekolah, K., Baureno, M. I., Kholida Yonas NIM, L., Komarudin, D., Hak, A. A., Ba, E. F. B., Puspasari, A., Murda, I. N., Arcana, I. N., ... Suresman, E. (2014). Ilmu Pendidikan Islam. TARBAWI.

Konsep pendidikan islam dalam keluarga menurut Prof. Dr. Zakiyah Darajat. (n.d.).

Kusumaningrum, D. E., Sumarsono, R. B., \& Gunawan, I. (n.d.). BERBASIS PESANTREN. 139-150.

Kusumawardhani, D. A., \& Malang, U. N. (2020). Analisis kepuasan peserta didik terhadap layanan evaluasi hasil belajar. 3, 90-101.

Lestari, N. M. C. P., Sutama, I. M., \& Utama, I. D. G. B. (2019). PENGEMBANGAN MEDIA PEMBELAJARAN VISUAL BAGI PEBELAJAR BIPA PEMULA DI UNDIKSHA. Jurnal Pendidikan Babasa Dan Sastra Indonesia Undiksha. https://doi.org/10.23887/jipbs.v8i1.20535

Muchith, M. S. (2016). Guru Pai Yang Profesional. Quality.

Muslimin, T. A., \& Kartiko, A. (2020). Pengaruh Sarana dan Prasarana Terhadap Mutu Pendidikan di Madrasah Bertaraf Internasional Nurul Ummah Pacet Mojokerto. Munaddhomah: Jurnal Manajemen Pendidikan Islam, 1(2), 75-87. https://pasca.jurnalikhac.ac.id/index.php/munaddhomah/article/view/30

Mustika, M., Sugara, E. P. A., \& Pratiwi, M. (2018). Pengembangan Media Pembelajaran Interaktif dengan Menggunakan Metode Multimedia Development Life Cycle. Jurnal Online Informatika. https://doi.org/10.15575/join.v2i2.139

Nasir, N. (2020). PENGEMBANGAN MEDIA PEMBELAJARAN PENDIDIKAN AGAMA ISLAM (PAI) BERBASIS WEB DI KELAS VIII SMP UNISMUH MAKASSAR. Akademika. https://doi.org/10.34005/akademika.v9i01.813

Oemar, H. (1978). Analasis Kebutuban. Rajawali Pers.

Peran sistem informasi manajemen (SIM) dalam pengambilan keputusan. (2013). Jumal Stie Semarang, 5(1), 26-37. 
Rofi'ah. (2020). Meningkatkan Motivasi Belajar Pendidikan Sejarah Kebudayaaan Islam Melalui Metode Pembelajaran Mind Mapping. Attadrib: Jurnal Pendidikan Guru Madrasah Ibtidaiyah, 3(2), 33-40. http://www.jurnal.staidagresik.ac.id/index.php/attadrib/article/view/109

Rony, \& Jariyah, S. A. (2020). Urgensi Pendidikan Karakter dalam Membentuk Akhlak Peserta Didik. Tafkir: Interdisciplinary Journal of Islamic Education, 1(1), 79-100. https://doi.org/10.31538/tijie.v1i1.18

Setiawan, A. (2019). MERANCANG MEDIA PEMBELAJARAN PAI DI SEKOLAH. Darul Ulum: Jurnal Ilmiah Keagamaan ....

Simangunsong, T., \& . M. (2015). PENGEMBANGAN MEDIA PEMBELAJARAN BERBASIS MULTIMEDIA PADA MATA PELAJARAN IPA DI SMP. JURNAL TEKNOLOGI INFORMASI \& KOMUNIKASI DALAM PENDIDIKAN. https://doi.org/10.24114/jtikp.v2i1.3288

Sj, D. S., Maarif, M. A., \& Zamroni, A. (2021). Strategi Pengembangan Program Pembelajaran Pendidikan Agama Islam Sekolah: The Development Strategy of Islamic Religious Education Learning Programs. Tafkir: Interdisciplinary Journal of Islamic Education, 2(1), 20 40. https://doi.org/10.31538/tijie.v2i1.21

Sugiono. (2015). Memahami Penelitian Kualitatif. Alfabeta.

Suharsimi, A. (2006). Prosedur penelitian suatu pendekatan praktik. Jakarta: Rineka Cipta.

Sundari, A. (2021). Manajemen Kegiatan Ekstrakurikuler Dalam Meningkatkan Prestasi Non Akademik Siswa. Munaddhomah: Jurnal Manajemen Pendidikan Islam, 2(1), 1-8. https://pasca.jurnalikhac.ac.id/index.php/munaddhomah/article/view/45

Sya'bani, M. A. Y., Sejati, Y. G., \& Fatmawati, A. F. (2020). Integrasi Nilai-Nilai Pendidikan Islam Wasatiyyah Melalui budaya Moderasi Beragama Sebagai Upaya Untuk Meningkatkan Kerukunan Dan Toleransi Umat Beragama Di Kebomas Gresik. Martabe: Jurnal.

Tajudin, A., \& Aprilianto, A. (2020). Strategi Kepala Madrasah..dalam Membangun Budaya Religius Peserta Didik. Munaddhomah: Jurnal Manajemen Pendidikan Islam, 1(2), 101-110. https://pasca.jurnalikhac.ac.id/index.php/munaddhomah/article/view/34

Taufiq Ari Nugroho, B. T., \& . M. (2019). PEMANFAATAN TEKNOLOGI INFORMASI DALAM PEMBELAJARAN PAI DI SD NEGERI CANDIREJO. Jurnal PROGRESS: Wabana Kreativitas Dan Intelektualitas. https://doi.org/10.31942/pgrs.v7i1.2722

Universitas Muhammadiyah Surakarta . Sekolah Pascasarjana, H. (2016). Profetika: Jurnal studi Islam. Profetika: Jurnal Studi Islam, 15(02), 160-174.

Wiyani, N. A. (2013). Menumbubkan Pendidikan Karakter di SD (Konsep, Praktek, dan Strategi). Ar Ruzz Media.

Zuhriyah, A. (2020). Pengembangan Media Pembelajaran Permainan Ular Tangga Untuk Meningkatkan Motivasi Belajar Siswa dan Hasil Belajar IPS di Madrasah Ibtidaiyah. Attadrib: Jurnal Pendidikan Guru Madrasah Ibtidaiyah, 3(2), 26-32. http://www.jurnal.staidagresik.ac.id/index.php/attadrib/article/view/110 